\title{
Green Real Estate: Does It Create Value? Financial and Sustainability Analysis on European Green REITs
}

\author{
Massimo Mariani ${ }^{1}$, Paola Amoruso ${ }^{1}$, Alessandra Caragnano $^{1} \&$ Marianna Zito ${ }^{1}$ \\ ${ }^{1}$ Department of Management, Lum University, Italy \\ Correspondence: Massimo Mariani, Department of Management, Lum University, Italy. E-mail: mariani@lum.it
}

Received: April 21, 2018

doi:10.5539/ijbm.v13n7p80
Accepted: May 16, 2018

Online Published: June 15, 2018

\begin{abstract}
Sustainability represents an innovative component of profitability for real estate finance, and among other instruments, real estate funds include a "green" component represented by certified buildings.

In particular, the adopted selection criteria refer to the two European most widespread certifications: LEED and BREEAM.

The objective is to demonstrate the degree of correlation between the adoption of implemented sustainable policies and financial performance. For this purpose Fama-French Five Factor Model has been applied.

This work is oriented in validating the hypothesis, which states that sustainable and environmentally friendly components positively affect the performances of investment portfolios, focusing on the European property management industry. Therefore, this paper has the ambitious aim of filling the gap in current literature on REITs mainly focused on the US market.
\end{abstract}

Keywords: REIT, performance, green, SRI, ESG, multifactor model

\section{Introduction}

Investors' consideration with respect to sustainable and ethical finance tends to go towards the expansion of investment vehicles with cultural, social and environmental inclination (Adamo, Federico and Notte, 2014). The need to combine profit oriented and social purposes in addition to the must of considering the ethics, which drives economic and financial behaviours, has improved (Adamo, 2009; Capriglione, 2004).

The dramatically increased spread of ethical finance, which focuses on environmental respect along with economic development and social responsibility, has led to the expansion of a committed financial segment, also known as Green Finance (Adamo, Federico and Notte, 2014). In particular, environmental concerns have improved the range of investment opportunities for "green funds", SRI funds that focus on responsible environmental investments, widely spreading the popularity of these vehicles in the last few decades (Climent \& Soriano, 2011).

Investments in renewable energy have been driven by policies aimed at improving cost-competitiveness and reduce climate change, enabling renewables to keep growing their portion of world electricity production at the expense of traditional carbon-emitting sources. Investors, businesses and governments are realising that the advancement towards climate-resilient low-emission growth is beneficial and already under way.

The current work focuses the attention on real estate sector, and particularly on the influence of green buildings inclusion in real estate portfolio on financial performance.

This paper presents a first part where academic findings are presented, in order to give a clear idea on what this paper is focusing on, and the basis from where the study arises. Applied methodology and selected data are fully described in the third part of this paper, where selection criteria and applied model are explained in detail. Finally the work findings invalidated our hypothesis on improvement of financial performances generated by green components. In fact, it has been demonstrated how, in the selected sample and during the selected time period, the percentage of certified building in the REITs portfolio have a negative impact on these performances while also improving the stocks' beta. 


\section{Literature Review}

There has been an intense growth in "green" private equity and infrastructure, with particular focus on renewable energy. Green investment as a term can refer to a sub-set of wider investment themes or can be related to investment approaches, for instance, environmental, social and governance investing (ESG), socially responsible investing (SRI), and long-term sustainable. Investors' commitment to climate changes and general green issues has been intensifying in the last decades and initiatives are rising in support.

Fascinatingly, investors have invested without been too concerned about standards and definition of "green" assets classes. Private equity is often seen as a starting point for green investments, being a common investment vehicle for new ventures of green technology. Moreover, given its crucial importance for economy and society, infrastructure has a strong connotation to several green themes such as climate change considering transport and communication facilities including energy efficiency, low emission development and climate adaptation.

Some managers use ESG or green overlay in their investment processes while others allocate certain percentages of assets to specific green products (Inderst, Kaminker and Stewart, 2012).

Porter and der Linde (1995) sustained that improving a company environmental performance can enhance financial or economic performance, without necessarily increasing costs.

Stefan and Paul (2008) provided empirical evidence of enhancement in environmental and financial performance demonstrating the "win-win" situation with potential revenue increase and cost reduction of environment-committed practices.

King and Lenox (2001) analysed 652 U.S. firms over the decade 1986-1996. The authors found evidence of a relationship between higher financial valuation and lower pollution suggesting that "When does it pay to be green?" may be a more significant question than "Does it pay to be green?". Slapikaite and Tamosiuniene (2013) compared SRI funds in the Baltic framework to the S\&P500 Total Return Index. The results showed greater return for SRI funds, which recovered significantly and faster after the global financial crisis, generally underlying positive results, therefore encouraging government and fund managers in developing countries to consider this as an opportunity to improve both economy and social welfare.

In contrast to the majority of existing studies, Chang, Nelson and Doug Witte (2012) obtained a divergent result, comparing performance of green and traditional mutual funds in the US framework considering a 15 years period. In their paper, the authors described the development and spread of green mutual funds in US markets, indicating that while initially driven by environmentally friendly behaviour of investors, the future of these type of funds will depend on their ability to generate competitive returns.

The question addressed by the authors is whether pursuing green investment goals, would sacrifice return performance empirically comparing operating characteristics, performances and risk measures of US green mutual funds and conventional mutual funds. Results of their paper indicate that the so-called "do-good" mutual funds in the US framework have not been able to generate competitive returns especially when compared to other mutual funds.

Green funds, exhibit lower risk-adjusted return and higher expense ratios, even though reporting lower annual turnover rates and lower tax cost ratio.

In terms of risk, Chang et al. indicated that green investment constraint seemed to produce a level similar to conventional funds. The results of their study indicated that green mutual funds underperformed over the considered period, suggesting that the funds must do better in the future to close the gap with their conventional peers.

The hope for green investors is that many companies are managing operations aiming at energy efficiency, intrinsically a green concept. When achieved, it may reduce costs and increase profits reflected in the stock price. Therefore, one route for green investors is to define "green" the ability of firms to achieve energy efficiency, which is more or less quantifiable.

In order to measure the sustainability and energy efficiency of buildings, a number of building rating schemes have recently been developed, such as the Leadership in Environmental and Energy Design (LEED) scheme initiated by the U.S. Green Building Council and the Energy Star program, jointly administered by the U.S. Environmental Protection Agency (EPA) and the Department of Energy.

Concerning corporate housing decisions, firms tend to consider the choice for more sustainable, energy efficient space, rather than conventional space for the following four reasons. The first reason is represented by direct economic benefits resulting from the occupancy of buildings with a green label. (Kok, Bauer, Eichholtz, \& 
Quigley, 2010).

Secondly, it is common knowledge that green buildings have a healthier indoor environment. For this reason, several studies have claimed to find a link between improved employee well being (through better indoor air quality) and enhanced productivity. (Apte, Fisk, \& Daisey, 2000).

Thirdly, green space could represent the social and environmental awareness of a firm and signal the ecological responsiveness of the corporation. The choice of green space may also enhance the ethical reputation of a firm, which may appeal to a certain segment of customers. Fourth, for some firms, but especially for governmental and non-profit organizations, environmental ideology may impose the strategic choice for green space.

The developed analysis has investigated the influence of green component on Real Estate Investment Trusts (REITs), giving a significant contribution to the literature of green buildings in the European real estate market. Among the most widespread measures in the U.S. by which a building can be considered being environmentally friendly there are the ENERGY STAR label system and the Leadership in Energy and Environmental Design (LEED) certification system. One of the most popular in the European landscape, together with LEED, is BREEAM (Building Research Establishment Environmental Assessment Method), which is an English method of evaluation and assessment of environmental quality in buildings, developed by the Building Research Establishment. Because the current work is focused on the European market, it will only refer to these last two certifications.

In general with reference to social investment in real estate, various works on responsible property investing (RPI) have been developed (Pivo \& McNamara, 2005; Pivo, 2009, 2010), showing that companies are oriented towards more sustainable real estate investments.

Specifically regarding investments in green buildings, Chijs (2008) conducted a study of office buildings in the U.S. market, finding evidence of higher rents and lower vacancies for green buildings. Similarly Eichholtz, Kok, and Quigley (2010) and Fuerst and McAllister (2011) found analogous results for rent premiums and occupancy rates. Similar results have been also showed by Nelson (2007), who looked at LEED and ENERGY STAR buildings, in the US market. Wiley, Benefield and Johnson (2010) have analysed 7.308 office properties LEED-certified and ENERGY STAR-certified, finding higher rents and higher occupancy for green buildings. Furthermore, Miller, Spivey, and Florance (2008) found evidence of the faster absorption on the market of green buildings, with a sales premium on LEED-certified buildings pricing. Eichholtz, Kok, and Yonder (2012) have been the first scholars to investigate the relationship between return performance of REITs and their green component, finding a positive relationship between the greenness of a REIT and their performance. Sah, Miller and Ghosh (2013) who showed that green REITs have a higher return on assets than traditional ones, have found similar results. They proved that there is superior stock performance by green REITs over their non-green peers. Benefits associated with green buildings, as compared to their counterparts, have also been tested by HinHo, Satyanarain and Ying Han (2013).

However, there is a general lack in literature about measuring the financial performance of REITs in the European framework, particularly via the Fama-French Five Factors model, also due to the relative youth of the method. It is known that asset pricing models focus on the magnitude of abnormal returns (Fama-French, 1993; Carhart, 1997). Several authors investigated REITs performances (as Redman \& Manakyan, 1995, Chui, Titman \& Wei, 2003), and more recently via Fama French models (Chiang, Lee, \& Wisen (2004), Lin, Rahman \& Yung, 2008). Eichholtz, Kok and Yonder (2012) investigate the effects of "green" commercial properties on the operating and stock performance of US REITs, providing evidence of the net benefits of green portfolio components. In their paper it is demonstrated that REITs with a larger portion of green properties display significantly lower market betas. More specifically, they performed multiple regressions, analysing the impact of variables such as the fund size age, Price to Book and the Debt ratio, and the age of the fund, in addition to green components, against dependent variables representing the REITs' financial performances (ROA, ROE, FFO, Alphas and Beta). In particular for the determination of funds' alphas they applied the CAPM based Fama French (1993) and Carhart (1997) four factor model. They documented the positive relationship between operating performance and the "greenness" of REITs, in addition to the absence of link between these and stock performance, deriving that stock prices reflect the higher cash flows generated by investments in more efficient properties.

Measuring performance applying the Sharpe's Capital Asset Pricing Model (CAPM) (Sharpe, 1966) has a long history and is actually still used. However, at a theoretical level, there have been strong oppositions to CAPM-based measures "The Roll's critique" (Roll, 1978; Dybvig \& Ross, 1985).

Applying the alpha measure the investor can determine if the portfolio gives the appropriate return level for its 


\section{level of risk. (Note 1).}

Essentially the alpha is the intercept from the CAPM regression of portfolio excess returns on the market portfolio in the sample period, representing the portion of return that cannot be attributed to common factors.

The generic Jensen's alpha regression suffers from the same drawbacks that characterised the CAPM methodology (Brown \& Reilly, 2009).

In the light of recent studies on fund performances, they now take into account multiple factors. Here the continuous development of multifactor models, which are able to capture effects relative to different frameworks, can affect the generation of abnormal returns. Empirically, several authors identified non-beta factors relevant in explaining the cross sectional variation in returns (Rosenberg et al., 1985; Fama \& French, 1993; Carhart, 1997; Bahl, 2006; Tripathi, 2008; Taneja, 2010). Eugene Fama and Kenneth French (1993) introduced their Multifactor model arguing that the performance of a managed portfolio should be analysed by considering additional factors. The superiority of the most recent Five Factor model (2015) has been widely demonstrated.

Several academics compared the CAPM and Fama-French Three Factor Model. The findings showed that the Fama-French Model is superior to the CAPM in explaining both stock returns and value premium effects (Bhatnagar \& Ramlogan, 2012). It demonstrates also how several variables are correlated with expected market returns, including long-term Government bond yield, book-to-market ratio, dividend yield, default premium, and term premium (Kothari \& Warner, 1998) and that there is evidence that the Fama-French measures are related to those variables, while the CAPM is not.

Chen et al. (2004) compared CAPM and Fama-French Three Factor Model analysing US diversified mutual funds (1962-1999). The authors considered the return of a one-month Treasury bill as risk free rate of return for the analysis. Again this study clearly showed how the multifactor model is preferred to the simple CAPM regression. Lately, Blanco (2012) as well as Bhatnagar and Ramlogan (2012) investigated the empirical failure of CAPM compared with Fama-French Three Factor model, demonstrating the superiority of the multi factor model. Adami et al. (2014), applied CAPM, Fama-French three factor and Fama-French Carhart (1997) models evaluating the performances of UK pension funds (1990-2008) finding that the models are significant in explaining the abnormal returns and that the Carhart momentum factor did not add significant effect to the model providing significantly greater alpha values.

Fama and French (2015), described five risk factors common in the returns on stock and bonds, and among these, three are related to the stock market: firm size, book-to-market equity and overall market; and two are related to the bond market: maturity and default risk (Note 2) and developed the most commonly used performance measurement model, the Fama-French Three (1993) and Five Factor Models (2015).The most recent five-factor model is directed to capture the value, profitability, investment patterns and size in returns, and it has been proved performing better than the Fama-French Three-Factor model (Fama and French, 2015). This model has been applied in this study.

\section{Methodology and Data}

Data have been collected from the Bloomberg terminal. The time period considered has been 6 years (July 2010June 2016) according to the time period selection suggested by Eugene Fama and Kennet French for the application of their state-of-the-art model.

REITs component of the FTSE EPRA/NAREIT Europe index have been shortlisted according to availability of data such as age (at least founded in 2010), total and green certified square metres under management, and other variables successively described; 52 real estate investment trusts have been elected as "Green" according to the percentage of certified squares metres under management. The minimum chosen threshold is $20 \%$ of sqm certified LEED or BREEAM as percentage of the whole property portfolio.

Moreover, it is worth specifying that the selection for this study has been chosen due to the availability of data provided by the academic subscription to the data vendor. The requirement for each fund in order to be included in the sample has been the availability of fund daily shares last prices and historical yearly, ROE, ROA, Price to Book ratio, Debt Ratio and Funds Total Assets, for the whole considered period (6 years); 26 trusts have been added to the sample as non-green REITs that are characterized by less than $20 \%$ or complete absence of green certified sqm under management.

As well as for the selected green trusts, the main constraint for the selection process has been the availability of historical data, which is the reason for the relatively small size of the sub-sample. The resulting sample contains 390 observations. 
A description of the Green REITs sample is presented in the Appendix.

The adjusted close prices for each fund in both the universes (Green and non-Green) have therefore been downloaded on a daily basis in order to calculate the monthly return provided by each REIT of the samples. Measuring returns versus prices led us to several benefits in econometric frameworks. For instance, the normalization, which enables evaluations of analytical relationship amongst different variables even though they are generated from series of prices values not having equal values can also be considered a requirement for several multidimensional statistical analyses.

Returns are generally calculated as:

$$
R i=\frac{P_{i}-P_{j}}{P_{j}}
$$

Where $\mathrm{Ri}$ is the Return at time $\mathrm{i}, \mathrm{Pi}$ is the price at time $\mathrm{I}$ and $\mathrm{j}=(\mathrm{i}-1)$.

However, when considering financial time series it is well known that the case is of non-normal distribution but it is plausible to assume log-normal distribution of prices (Danielsson, 2011).

In other words, log-returns are conveniently normally distributed since:

$$
1+R i=\frac{P_{i}}{P_{j}}=\exp ^{\log \left(\frac{P_{i}}{P_{j}}\right)}
$$

This is one of the several theoretical and algorithmic benefits in considering log returns, calculated as:

$$
R i=\log P_{i}-\log P_{j}=\log \frac{P_{i}}{P_{j}}
$$

Moreover, considering that the returns are small (particularly for small trading durations), they are close in value to raw returns, assertion explicable by approximating:

$$
\log (1+r) \approx r, r \ll 1
$$

In other words, $\log$ returns approximate raw-log equality. Other advantages are time - additivity and numerical stability (Hudson and Gregoriou, 2015). The returns have been calculated gross of taxes and expenses due to the lack of availability in historical data for expense ratio and managerial fees. The whole sample has then been sorted by historical Assets under Management as indicator of historical size of the investment trust, as performed by Adami et al. (2014).

Considering a stock portfolio, sorting the sample by size enhances the power of tests reducing the error measurement, solving the concerns related to data mining (Lo \& McKinlay, 1990). Daily Fama French Five Factors for the selected period have been downloaded from the Kenneth French Database for the European Market (French, 2016) and the Risk Free Rate of return (as return on US 1 month Treasury bill) has been downloaded from the U.S. Department of the Treasury website. Subsequently, monthly excess returns have been calculated as the monthly return in excess of risk free (Note 3 ) rate of return for all the REITs.

$$
\text { Excess Return }=\mathrm{Ri}-\mathrm{Rf}
$$

Stationarity of time series can "strongly influence its behaviour and properties" (Brooks, 2014). Non-stationarity time series present characteristics such as autocorrelation, variance and mean constant over time. The study performed data test for non-stationarity, with the aim of ascertaining the absence of unit-root (Note 4).

Moreover, Brooks argued that using non-stationary data can lead to spurious regression and that the common assumptions for asymptotic analysis could not be valid. This can lead to biasing the output of statistical tests and even the overall validity of these models. Ensuring the non-stationarity of the data, and therefore the non-normal distribution, the study proceeded.

The Augmented Dickey-Fuller tests for non-stationarity outputs (Note 5) has been performed on all the REITs calculated excess returns as well as for the five factors variables. The null hypothesis of non-stationarity in the time series has been remarkably rejected and the test concluded that there is stationarity in the considered time series, accepting the alternative hypothesis. The statistical diagnostics, proceeded by testing for normality.

The Jarque-Bera (Note 6) (1987) figures rejected the null hypothesis of normality even at a $99.5 \%$ confidence level present $\mathrm{p}$-values $=0.00$. Absence of normality has been ascertained for the whole REITs universe. Skewness and Kurtosis values, respectively different from 0 and 3 and the JB values, rejected the hypothesis of normal distribution instead of heavy tailed distribution (DeCarlo, 1997; Fernández \& Steel, 1998).This is a 
common condition when analysing financial data, which is likely to present leptokurtic (Note 7) or platykurtic (Note 8) tails in their distributions (Verhoeven \& McAleer, 2004).

In these cases, values of kurtosis $>3$ indicate leptokurtic distributions.

Multicollinearity test showed small value of correlation between excess returns and the risk factors and the null hypotheses of multicollinearity (Note 9) were therefore rejected for all the performed regressions (Note 10).

Sharpe Ratio, Treynor Ratio and Jansen alpha have largely been analysed by several academic studies, which have strongly proven the limitation of these traditional methodologies, claiming the superiority of the more recent Multi Factor Models (Note 11). It is well known that asset pricing models focus on the magnitude of the abnormal returns (Fama-French, 1993; Carhart, 1997) and these tests developed by combining portfolios alphas can be more powerful.

Therefore, the study proceeded estimating individual annualized Alphas and Betas (as the coefficient of the market risk premium in the regression) for each REIT assessed via the Fama French Five Factor model (Note 12) by OLS estimation.

$$
\mathrm{Ri}_{\mathrm{t}}-\mathrm{RF}_{\mathrm{t}}=\alpha_{\mathrm{i}}+\beta_{\mathrm{i}}\left(\mathrm{RM}_{\mathrm{t}}-\mathrm{RF}_{\mathrm{t}}\right)+\mathrm{s}_{\mathrm{i}} \mathrm{SMB}_{\mathrm{t}}+\mathrm{h}_{\mathrm{i}} \mathrm{HML}_{\mathrm{t}}+\mathrm{r}_{\mathrm{i}} \mathrm{RMW}_{\mathrm{t}}+\mathrm{c}_{\mathrm{i}} \mathrm{CMA}_{\mathrm{t}}+\varepsilon_{\mathrm{it}}
$$

In this equation (Fama \& French, 2014):

$\mathrm{Ri}_{\mathrm{t}}$ "Represents the return on the portfolio or security $\mathrm{i}$ at time $\mathrm{t}$ ",

$\mathrm{RF}_{\mathrm{t}}$ "Is the risk free return at time $\mathrm{t}$ ",

$\mathrm{RM}_{\mathrm{t}}$ "Is the return on the value weighted market portfolio (VW)",

$\mathrm{SMB}_{\mathrm{t}}$ "Represents the return on a diversified portfolio of small stocks minus the return on a diversified portfolio of big stocks",

HML $_{\mathrm{t}}$ "Is the difference between the return on diversified portfolios of high and low book to market stock",

$\mathrm{RMW}_{\mathrm{t}}$ "Is the difference between the returns on diversified portfolios of stocks with robust and weak profitability" and

$\mathrm{CMA}_{\mathrm{t}}$ "Is the difference between the return diversified portfolios of the stocks of low and high investment firms, which we call conservative and aggressive"

$\varepsilon_{\text {it }}$ "Is a zero-mean residual".

The model is directed at capturing the value, profitability, investment patterns and size in returns, and it has been proved that it performs better than the Fama-French Three-Factor model (Fama and French, 2014).

In order to obtain reliable empirical results when performing regression analyses, particularly in financial time series, it is crucial to consider several statistical properties.

Coefficients of OLS estimation must be BLUE, showing low value of MSE (Mean Squared Error) (Austeriou et al. 2012). A condition, where regressions present lags with Heteroscedasticity (Note 13) or Autocorrelation (Note 14), has the consequence of coefficients which are not BLUE therefore they are biased and inconsistent. Thus, in order to obtain reliable and efficient estimated coefficients and unequivocal hypothesis tests, it is required to adjust the data or choose different estimation methodologies. As proven by performed white test (White, 1980) and via graphical procedures providing ACF (Note 15) and PACF ( ${ }^{N}$ ote 16) plot representations the performed regressions have been found clean from Heteroscedasticity and Autocorrelation.

It is worth specifying that the autocorrelation $\mathrm{AC}$ for a white noise process $\left({ }^{\mathrm{N}}\right.$ ote 17$)$ will be zero except for peak $=1$ at $\mathrm{s}=0$.

The selected model for this study has been inspired by the work of Eichholtz, Kok, and Yonder (2012), as:

Equation 1: $\mathrm{ROA}_{\mathrm{it}}=\alpha+\beta_{1} \ln (\text { Total Assets })_{\mathrm{i}}+\beta_{2}$ PriceBook Ratio $_{\mathrm{i}}+\beta_{3}$ Debt Ratio $_{\mathrm{i}}+\beta_{4} \mathrm{Sqm}_{\mathrm{i}}+\beta_{5}$ Age $_{\mathrm{i}}+$ $\beta_{6}$ Greenness $_{\mathrm{i}}+\varepsilon_{\mathrm{i}}$

Equation 2: ROE $_{i t}=\alpha+\beta_{1} \ln (\text { Total Assets })_{i}+\beta_{2}$ PriceBook Ratio $_{i}+\beta_{3}$ Debt Ratio $_{i}+\beta_{4}$ Sqm $_{i}+\beta_{5}$ Age $_{i}+$ $\beta_{6}$ Greenness $_{\mathrm{i}}+\varepsilon_{\mathrm{i}}$

Equation 3: Alpha $_{i t}=\alpha+\beta_{1} \ln (\text { Total Assets })_{i}+\beta_{2}$ PriceBook Ratio $_{i}+\beta_{3}$ Debt Ratio $_{i}+\beta_{4}$ Sqm $_{i}+\beta_{5}$ Age $_{i}+$ $\beta_{6}$ Greenness $_{\mathrm{i}}+\varepsilon_{\mathrm{i}}$

Equation 4: Beta $_{i t}=\alpha+\beta_{1} \ln (\text { Total Assets })_{i}+\beta_{2}$ PriceBook Ratio $_{i}+\beta_{3}$ Debt Ratio $_{i}+\beta_{4}$ Sqm $_{i}+\beta_{5}$ Age $_{i}+$ 
$\beta_{6}$ Greenness $_{\mathrm{i}}+\varepsilon_{\mathrm{i}}$

Multicollinearity check is reported in the Appendix.

Dependent Variables:

$\mathrm{ROA}_{\mathrm{i}}$ is the historical Return on Assets,

$\mathrm{ROE}_{\mathrm{i}}$ is the historical Return on Equity,

$\mathrm{Alpha}_{\mathrm{i}}$ is the intercept from the Fama-French Five Factors Model.

Beta $_{\mathrm{i}}$ is the market risk premium coefficient from the Fama-French Five Factor Model.

Independent Variables are:

Ln (Total Assets) is the natural logarithm of the REITi total assets at time t.

PriceBookRatio is the historical Price to Book Ratio of the REITi at time $t$.

Debt Ratio is the debt to asset ratio of the REITi at time $t$.

$\mathrm{Sqm}_{\mathrm{i}}$ is the total square metres under management of REITi at time t.

$\mathrm{Age}_{\mathrm{i}}$ is the years since the IPO of REITi at time t.

Greenness $\mathrm{C}_{\mathrm{i}}\left(\mathrm{N}^{\mathrm{O}}\right.$ ote 18$)$ is a categorical dummy variable that assumes values of 1 if the $\mathrm{REIT}_{\mathrm{i}}$ portfolio is characterized by a percentage of green certified square metres at least equal to $20 \% ; 0$ otherwise.

The term $\varepsilon_{\mathrm{i}}$ is the error term.

Considering the number of selected REITs and the time-period (2011-2016), 390 totally' observations compose the selected sample.

Table 1. Summary statistics for the selected sample (390 observations)

\begin{tabular}{|c|c|c|c|c|c|c|c|c|c|c|c|c|}
\hline & \multicolumn{7}{|c|}{ Descriptive Satistics } & \multirow{2}{*}{\multicolumn{5}{|c|}{ Non-Gren }} \\
\hline \multirow[t]{2}{*}{ Variable } & \multicolumn{4}{|c|}{ All Observations } & \multicolumn{3}{|c|}{ Green } & & & & & \\
\hline & Mean & Std. Dev. & Obs. & & Mean & Std. Dev. & Obs. & & Mean & Std. Dev. & Obs. & \\
\hline \multicolumn{13}{|l|}{ Dependent Variables } \\
\hline Reurn on A saets (\%) & 4.093175 & 7.42055 & & 390 & 4.56699 & 6.595468 & & 260 & 3.14554 & 8.79503 & & 130 \\
\hline Reusrn on Equiry (\%) & 5.847016 & 30.5549 & & 390 & 8.5672 & 15.90057 & & 260 & 0.40666 & 47.5701 & & 130 \\
\hline A pha (Annualised \%) & -0.1226 & 0.00252 & & 390 & -0.1232 & 0.002613 & & 260 & -0.1215 & 0.23266 & & 130 \\
\hline Beta & 0.962234 & 0.07203 & & 390 & 0.96106 & 0.069339 & & 260 & 0.06458 & 0.07737 & & 130 \\
\hline \multicolumn{13}{|l|}{ Control Variables } \\
\hline Ln(Tota1 Asse ts) & 7.623485 & 1.670229 & & 390 & 8.40603 & 1.226324 & & 260 & 6.05839 & 1.30328 & & 130 \\
\hline Prize-Book Ratio & 1.109644 & 0.59555 & & 390 & 1.19751 & 0.55654 & & 260 & 0.93392 & 0.63323 & & 130 \\
\hline Debt Ratio & 23.63601 & 100.034 & & 390 & 27.7445 & 120.7694 & & 260 & 15.4189 & 28.1062 & & 130 \\
\hline Sqm & 17725586 & $1.3 \mathrm{E}+08$ & & 390 & $2.6 \mathrm{E}+07$ & $1.53 \mathrm{E}+08$ & & 260 & 1106118 & 1331630 & & 130 \\
\hline Age & 34.11538 & 37.5441 & & 390 & 29.1154 & 30.37771 & & 260 & 44.1154 & 473985 & & 130 \\
\hline Greeness & 0.666667 & 0.47201 & & 390 & 1 & 0 & & 260 & 0 & 0 & & 130 \\
\hline
\end{tabular}

Table 2. Estimation outputs

\begin{tabular}{|c|c|c|c|c|c|c|c|}
\hline \multicolumn{8}{|c|}{ Financial Performances } \\
\hline 1 - ROA & Coeff. & $\mathrm{t}$-Stat & Prob. & $2-\mathrm{ROE}$ & Coeff. & t-Stat & Prob. \\
\hline Ln(Total Assets) & $6.59 \mathrm{E}-02$ & 4.68122 & $0.0037^{* * *}$ & Ln(Total Assets) & 0.036329 & 3.95729 & $0.0099^{* * *}$ \\
\hline Price-Book Ratio & 0.092184 & 2.23613 & $0.0129 * *$ & Price-Book Ratio & -0.092235 & -5.8241 & $0.0001 * * *$ \\
\hline Debt Ratio & $4.66 \mathrm{E}-03$ & 1.84008 & $0.0811 *$ & Debt Ratio & -0.001500 & -0.1149 & 0.2555 \\
\hline Age & $1.78 \mathrm{E}-02$ & 1.68519 & $0.0842 *$ & Age & 0.020273 & 0.51382 & 0.8237 \\
\hline Sqm & $-7.53 \mathrm{E}-10$ & -1.2903 & 0.6603 & Sqm & 2.13E-09 & 0.05988 & 0.8402 \\
\hline Greeness & $-3.43 \mathrm{E}-01$ & -2.5437 & $0.0807 * *$ & Greeness & 0.382473 & 0.36169 & 0.5355 \\
\hline R2 & \multicolumn{2}{|c|}{$0.51075 \mathrm{DW}$} & 2.0224 & R2 & \multicolumn{2}{|c|}{$0.80913 \mathrm{DW}$} & 1.9662 \\
\hline Prob. & \multicolumn{2}{|c|}{$1.04 \mathrm{E}-07$} & & Prob. & \multicolumn{2}{|c|}{0.000013} & \\
\hline 3- Alpha & Coeff. & $\mathrm{t}$-Stat & Prob. & 4 - Beta & Coeff. & $\mathrm{t}$-Stat & Prob. \\
\hline Ln(Total Assets) & $4.91 \mathrm{E}-05$ & 0.60193 & 0.6183 & Ln(Total Assets) & 0.001509 & 0.41086 & 50.5924 \\
\hline Price-Book Ratio & 0.000415 & 1.89085 & $0.0683 *$ & Price-Book Ratio & 0.007917 & 0.54143 & 0.2239 \\
\hline Debt Ratio & $-8.51 \mathrm{E}-07$ & -0.1801 & 0.5157 & Debt Ratio & $-6.30 \mathrm{E}-05$ & -2.5165 & $0.0953 *$ \\
\hline Age & 4.26E-06 & 0.98167 & 0.2491 & Age & 0.000130 & 0.56678 & 0.2171 \\
\hline $\mathrm{Sqm}$ & $1.42 \mathrm{E}-12$ & 1.9881 & $0.0174 * *$ & $\mathrm{Sqm}$ & $4.26 \mathrm{E}-11$ & 0.60845 & 0.1551 \\
\hline Greeness & $-8.05 \mathrm{E}-04$ & -6.9964 & $0.0016 * * *$ & Greeness & 0.002500 & 2.57562 & $0.0786 *$ \\
\hline R2 & \multicolumn{2}{|c|}{$0.8108 \mathrm{DW}$} & 1.8646 & R2 & \multicolumn{2}{|c|}{$0.6833 \mathrm{DW}$} & 1.8408 \\
\hline Prob. & \multicolumn{2}{|c|}{$1.22 \mathrm{E}-08$} & & Prob. & \multicolumn{2}{|c|}{$1.13 \mathrm{E}-06$} & \\
\hline
\end{tabular}

*indicates significance at the 10 percent level.

**indicates significance at the 5 percent level.

***indicates significance at the 1 percent level. 
Investigating the impact of these variables on operating performances (Equation 1 and 2), from the Equation 1, it is evident that all the considered variables have different but significant effects on the $R O A$, except the variable $S q m$, as shown by the p-values. Particularly the variable Greenness has a negative impact on the ROA at $5 \%$ significance level ( $\mathrm{p}$-value $<0.05$ ).

The Goodness of Fit statistics, numerically explained by the values of $R^{2}$ of the performed regressions, can be considered as efficient statistics to describe the goodness of fit of a model. In other words, according to Brooks (2014), the $R^{2}$ describes how well the model fits the data, and therefore how well the explanatory variables explain the dependent variable in the regression. The $R^{2}$ indicates that the model has a $51 \%$ explanatory power at $1 \%$ significance level, due to the significantly low $\mathrm{p}$-value ( $\mathrm{p}$-vale $<0.001$ ).

The Durbin-Watson statistics DW (Note 19) of 2.0224 indicates absence of autocorrelations, as from the related Durbin Watson test $(\mathrm{n}=390, \mathrm{k}=6$ not including the intercept, $\mathrm{dl}=1.613, \mathrm{dU}=1.735)$ (Note 20) which accept the null hypothesis of absence of significant autocorrelation at $5 \%$ confidence level $(\mathrm{dU}<\mathrm{d}<4-\mathrm{dU}=1.735<$ $2.0224<2.265$ ).

In case of autocorrelation the OLS estimators are still unbiased and consistent but inefficient because it is possible to find alternative unbiased estimators with smaller variance. (As for heteroscedasticity). The OLS estimators will be no longer BLUE and inefficient, standard errors are underestimated and $\mathrm{R}^{2}$ would be overestimated and the t-statistics will tend to be higher. (Asteriou \& Hall, 2011). However this is not the case.

The Equation 2, demonstrates that only the Ln (Total Assets) variable and the Price to Book Ratio one have a significant impact on the $R O E$ value at $1 \%$ significance level. The variable Greenness in this case has not resulted significant in affecting the $R O E$ of the REITs. The $R^{2}$ value indicates a $80.9 \%$ explanatory power of the model, at $1 \%$ significance level.

The Durbin-Watson statistics (DW) of 1.9662 indicates absence of significant autocorrelations with $5 \%$ confidence level $(\mathrm{dU}<\mathrm{d}<4-\mathrm{dU}=1.735<1.9662<2.265)$.

Assessing the impact of the variables on stocks performances (Equations 3 and 4), the Equation 3 shows that the REITs Alphas are positively affected by Price to Book Ratio at 10\% significance level, and by the total square meters in portfolio (Sqm) at 5\% significance level. The Greenness component has again a relatively small, but negative impact on the REITs performances.

The applied model presents goodness of fit statistic value of $81.08 \%$ at $1 \%$ significance level ( $p$-value of 1.22E-08).The Durbin-Watson statistics (DW) of 1.8646 indicates absence of significant autocorrelations with 5\% confidence level $(\mathrm{dU}<\mathrm{d}<4-\mathrm{dU}=1.735<1.8646<2.265)$.

Lastly, the Equation4 shows the impact of these variables on REITs Stock's Betas. In this case, the Debt Ratio negatively affects the dependent variable at $10 \%$ significance level (p-value $<0.1$ ) while the Greenness component has a positive impact on the stocks' performance at a $10 \%$ significance level.

The Durbin-Watson statistics (DW) of 1.8408 indicates absence of significant autocorrelations with $5 \%$ confidence level $(\mathrm{dU}<\mathrm{d}<4-\mathrm{dU}=1.735<1.8408<2.265)$.

This last applied model presents a R2 of 0.6833 at $1 \%$ confidence level.

\section{Conclusion}

The rationale of this study arises from results of abundant academic literature that investigated REITs performances and Green impact in the US market, questioning whether pursuing sustainable objectives would improve financial performance (Eichholtz, Kok, \& Yonder, 2012).

This work has been oriented in validating the hypothesis, which states that such green components can positively affect investment portfolios, focusing on the European framework. The applied methodology is a fundamental component of the uniqueness of this study in addition to the fact that such a study has never been performed for the observed regions. The performed analysis demonstrated that the percentage of certified building in the European REITs portfolios has a negative impact on ROA, ROE and stocks' alphas while also improving the stocks' beta. This can be mainly due to the incremented costs related to the refurbishments and adjustments processes needed to obtain the BREEAM and LEED certification. This study invalidated the recent theory on the positive impact of green components in funds portfolios as from Eichholtz, Kok, and Yonder (2012).

The hope for green investors is that aiming at sustainable goals, costs may be reduced and profits increased, and this would be reflected in stocks and financial performances.

However, this presented work empirically validated the Chang et. all theory (2012), stating that pursuing green 
investment goals could sacrifice return and financial performances, as this has been the case.

Considerations have to be made regarding the sample selection that has been affected by the availability of historical data. Further studies could consider the historical changes in green certified green squares metres under management, as this, which can be considered the main limitation of the whole study, could improve the reliability of the results and the model as a whole.

\section{References}

Adami, R., Gough, O., Mukherjee, S., \& Sivaprasad, S. (2014). An empirical analysis of the performance of pension funds: evidence from UK. Studies in Economics \& Finance 31(2), 141-155. https://dx.doi.org/10.1108/SEF-10-2012-0118.

Adamo, R. (2009). La finanza etica. Principi, strumenti e finalità. Naples: Edizioni Scientifiche Italiane, $129-178$.

Adamo, R., Federico, D., \& Notte, A. (2014). Performance and risk of green funds; Investment Management and Financial Innovations, 11(1), 134-145. https://doi.org/10.21511/imfi

Apte, M. G., Fisk, W. J., \& Daisey J. M. (2000). Associations between Indoor Co2 Concentration and Sick Building Syndrome Symptoms in US Office Buildings: An Analysis of the 1994-1996 Base Study Data. Indoor Air, 10, 256-27.

Asteriou, D., \& Hall, S. (2011). Applied econometrics. England: Palgrave Macmillan.

Bahl, B. (2006). Testing the Fama and French Three-Factor Model and Its Variants for the Indian Stock Returns. Working Paper, SSRN Electronic Journal. https://doi.org/10.2139/ssrn.950899

Blanco, B. (2012). The use of CAPM and Fama and French Three Factor Model: portfolios selection. Public and Municipal Finance, 1(2), 61-70.

Brooks, C. (2014). Introductory econometrics for finance. Cambridge: Cambridge University Press. https://doi.org/10.1002/ijfe.223

Brown, K., \& Reilly, F. (2009). Analysis of investments and management of portfolios. South-Western.

Capriglione, F. (2004). Etica della finanza, mercato, globalizzazione. Cacucci Editore.

Carhart, M. (1997). On Persistence in Mutual Fund Performance. The Journal of Finance, 52(1), 57-82. https://doi.org/10.2307/2329556

Chang, C. E., Nelson, W. A., \& Witte, H. D. (2012). Do green mutual funds perform well? Management Research Review 35(8), 693-708. https://doi.org/10.1108/01409171211247695

Chen, J., Hong, H., Huang, M., \& Kubik, J. (2004). Does Fund Size Erode Mutual Fund Performance? The Role of Liquidity and Organization. American Economic Review, 94(5), 1276-1302. https://doi.org/10.1257/0002828043052277

Chiang, K., Kozhevnikov, K., Lee, M., \& Wisen, C. (2006). REIT Mimicking Portfolio Analysis. International Real Estate Review, 9(1), 95-111. https://doi.org/10.1111/j.1540-6229.2008.00206.x

Chijs, V. D. (2008). Green building performance. An investigation of real estate investment opportunities. Maastricht University. https://doi.org/10.15396/eres1998_150

Chui, A., Titman, S., \& Wei, K. (2003). The Cross Section of Expected REIT Returns. Real Estate Economics 31(3), 451-479. https://doi.org/10.1111/1540-6229.00073

Climent, F., \& Soriano, P. (2011). Green and Good? The Investment Performance of US Environmental Mutual Funds. Journal of Business Ethics, 103(2), 275-287. https://doi.org/10.1007/s10551-011-0865-2

Daníelsson, J. (2011). Financial risk forecasting: The theory and practice of forecasting market risk, with implementation in R and Matlab. Chichester: John Wiley. https://doi.org/10.1002/9781119205869.ch1

Dickey, D., \& Fuller, W. (1979). Distribution of the Estimators for Autoregressive Time Series with a Unit Root. Journal of the American Statistical Association, 74(366), 427-431. https://doi.org/10.2307/2286348

Dybvig, P., \& Ross, S. (1985). Yes, The APT is Testable. The Journal of Finance, 40(4), 1173. https://doi.org/10.1111/j.1540-6261.1985.tb02370.x

Eichholtz, P., Kok, N., \& Yonder, E. (2012). Portfolio greenness and the financial performance of REITs. Journal of International Money and Finance, 31(7), 1911-1929. https://doi.org/10.1016/j.jimonfin.2012.05.014 
Eichholtz, P., Kok, N., \& Quigley, M. (2010). Doing Well by Doing Good? Green Office Buildings. American Economic Review, 100, 2494-251. https://doi.org/10.1257/aer.100.5.2492

Fama, E., \& French, K. (2015). A five-factor asset pricing model. Journal of Financial Economics, 116(1), 1-22. https://doi.org/10.1016/j.jfineco.2014.10.010

Fama, F. E., \& French, R. K. (1993). Common risk factors in the returns on stocks and bonds. Journal of Financial Economics, 33(1), 3-56. https://doi.org/10.1016/0304-405x(93)90023-5

Fernández, C., \& Steel, M. (1998). On Bayesian Modeling of Fat Tails and Skewness. Journal of the American Statistical Association, 93(441), 359-371. https://doi.org/10.1080/01621459.1998.10474117

Fuerst, F., \& McAllister, P. (2011). Green Noise or Green Value? Measuring the Effects of Environmental Certification on Office Values. Real Estate Economics, 39(1), 45-69. https://doi.org/10.1111/j.1540-6229.2010.00286.x

Hin Ho, K. D., Satyanarain, R., \& Ying Han, L. (2013). “Green” buildings and Real Estate Investment Trust's (REIT) performance. Journal of Property Investment \& Finance, 31(6), 545-574. https://doi.org/10.1108/jpif-03-2013-0019

Hudson, R., \& Gregoriou, A. (2015). Calculating and comparing security returns is harder than you think: A comparison between logarithmic and simple returns. International Review of Financial Analysis, 38, 151-162. https://doi.org/10.1016/j.irfa.2014.10.008

Inderst, G., Kaminker, C., \& Stewart, F. (2012). Defining and Measuring Green Investments: Implications for Institutional Investors “Asset Allocations”. OECD Working Papers on Finance, Insurance and Private Pensions, 24. https://doi.org/10.1787/5k9312twnn44-en

Jarque, C., \& Bera, A. (1987). A Test for Normality of Observations and Regression Residuals. International Statistical Review / Revue Internationale de Statistique, 55(2),163. https://doi.org/10.2307/1403192

King, A. A., \& Lenox, M. J. (2001). Does it really pay to be green? An empirical study of firm environmental and financial performance: An empirical study of firm environmental and financial performance. Journal of Industrial Ecology, 5(1), 105-116. https://doi.org/10.1162/108819801753358526

Kok, N., Bauer, R., Eichholtz, P., \& Quigley, J. M. (2010). How green is your property portfolio? The environmental performance of commercial Real Estate. University of California, Berkeley.

Kothari, S., \& Warner, J. (1998). Evaluating Mutual Fund Performance. The Journal of Finance, 56(5), 1985-2010. https://doi.org/10.1111/0022-1082.00397

Lin, C. Y., Rahman, H., \& Yung, K. (2009). Investor Sentiment and REIT Returns. Journal of Real Estate Finance and Economics, 39, 450-471. https://doi.org/10.1007/s11146-008-9115-5

Lo, A. W., \& MacKinlay, A. C. (1990). Data-snooping biases in tests of financial asset pricing models. Review of Financial Studies, 3, 431-467. https://doi.org/10.1093/rfs/3.3.431

Miller, N., Spivey, J., \& Florance, A. (2008). Does green pay off? Journal of Real Estate Portfolio Management, 14(4), 385-400.

Nelson, A. (2007). The Greening of U.S. Investment Real Estate - Market Fundamentals, Prospects and Opportunities. RREEF Research Report No. 57.

Pivo, G. (2009). Social and environmental metrics for US real estate portfolios: Sources of data and aggregation methods, Journal of Property Investment \& Finance, 27(5), 481-510. https://doi.org/10.1108/14635780910982359

Pivo, G., (2010). Owner-tenant engagement in sustainable property investing. Journal of Sustainable Real Estate 2(1), 184-199.

Pivo, G., \& McNamara, P. (2005). Responsible Property Investing, International Real Estate Review, 8(1), 128-143.

Porter, M. E., \& Der Linde, C. V. (1995). Toward a New Conception of the Environment-Competitiveness Relationship. The Journal of Economic Perspectives, 9(4), 97-118. https://doi.org/10.1257/jep.9.4.97

Redman, A., \& Manakyan, H. (1995). A multivariate analysis of REIT performance by financial and real asset portfolio characteristics. The Journal of Real Estate Finance and Economics, 10(2), 169-175. https://doi.org/10.1007/bf01096988 
Roll, R. (1978). Ambiguity when Performance is Measured by the Securities Market Line. The Journal of Finance, 33(4), 1051. https://doi.org/10.1111/j.1540-6261.1978.tb02047.x

Rosenberg, B., Reid, K., \& Lanstein, R. (1985). Persuasive evidence of market inefficiency. Journal of Portfolio Management, 11, 9-17. https://doi.org/10.3905/jpm.1985.409007

Sah, V., Miller, N., \& Ghosh, B. (2013). Are Green REITs Valued More? Journal of Real Estate Portfolio Management, 19(2), 169-177.

Savin, N., \& White, K. (1977). The Durbin-Watson Test for Serial Correlation with Extreme Sample Sizes or Many Regressors. Econometrica, 45(8). https://doi.org/10.2307/1914122

Sharpe, W. (1966). Mutual Fund Performance. Journal of Business, 39(1), 119-138. https://doi.org/10.1086/294846

Slapikaite, I., \& Tamosiuniene, R. (2013). Socially Responsible Mutual Funds - A Profitable Way of Investing, Scientific Annals of the "AlexandruIoanCuza" University of Iaşi. Economic Sciences, 60(1), 199-212. https://doi.org/10.2478/aicue-2013-0017

Stefan, A., \& Paul, L. (2008). Does It Pay to Be Green? A Systematic Overview. Academy of Management Perspectives, 22(4), 45-62. https://doi.org/10.5465/amp.2008.35590353

Taneja, Y. (2010). Revisiting Fama French Three-Factor Model in Indian Stock Market. Vision: The Journal of Business Perspective, 14(4), 267-274. https://doi.org/10.1177/097226291001400403

Tripathi, V. (2008). Company Fundamentals and Equity Returns in India. SSRN Electronic Journal, https://doi.org/10.2139/ssrn.1134651

Verhoeven, P., \& McAleer, M. (2004). Fat tails and asymmetry in financial volatility models. Mathematics and Computers in Simulation, 64(3-4), 351-361. https://doi.org/10.1016/s0378-4754(03)00101-0

Wiley, J. A., Benefield, J. D., \& Johnson, K. H. (2010). Green Design and the Market for Commercial Office Space, The Journal of Real Estate Finance and Economics, 41(2), 228-243. https://doi.org/10.1007/s11146-008-9142-2

\section{Notes}

Note 1. A positive value of alpha indicates that the portfolio is gaining excess returns and the manager is beating the market with his strategy.

Note 2. Must be taken into account that return on a stock are related to both stock and bond market.

Note 3. Excess returns are the investment returns that exceed the return of the risk free rate of return provided by an alternative risk free investment in as a 1 month T-Bill issued by the US government.

Note 4. Null hypothesis is presence of Unit Root or Non-Stationarity in the time series, whether the alternative Hypothesis is presence of Stationarity in the considered time series.

Note 5. $A D F=\Delta y_{t}=\psi y_{t-1}+\sum_{i=1}^{p} \alpha_{i} \Delta y_{t-1}+u_{t}$ where t-stat $=\frac{\bar{\psi}}{\widehat{S E}(\widehat{\psi})}$

Note 6. $J B=n\left[\frac{\hat{S}^{2}}{3 !}+\frac{(\widehat{R}-3)^{2}}{4 !}\right] \sim \chi_{\alpha, 2}^{2}$

Note 7. Kurtosis $>3$.

Note 8 . Kurtosis $<3$.

Note 9. Multicollinearity on the OLS estimators may affect the statistical significance of the estimated coefficients, due to the large standard error values.

There are two different type of multicollinearity: perfect and imperfect.

Considering the perfect multicollinearity, we are unable to calculate the OLS estimator and the condition is very difficult to find.

Imperfect multicollinearity is more common, since the correlation between variables is not perfect, but large enough to cause variances. Under this condition the regression coefficient is unbiased and significant and the error term is larger (Asteriou \& Hall, 2011). 
Note 10. Absence of relevant multicollinearity between dependent and independent variables is evident, as correlation values are negative or relatively small. OLS requirements are satisfied.

Note 11. Sharpe Ratio, in instance, has the drawback of ignoring diversification potential of portfolios and assess relative performance for different portfolio compositions.

Treynor's Ratio does not takes into account the unsystematic risk in a portfolio, and lastly the generic Jensen's alpha regression suffers from the same limitation of CAPM. (Brown \& Reilly, 2009)

Note 12. "If the exposures to the five factors, $\beta \_$i,s_i,h_i,r_i and c_i capture all the variation in the expected returns, the intercept $\alpha \_$i will be zero for all the securities and portfolios i." (Fama \& French, 2014).

Note 13. In case of persistence of heteroscedasticity, The OLS estimators are still unbiased and consistent because the explanatory variables are not correlated with the error term.

Furthermore, the OLS estimators are inefficient because there is the possibility to find other unbiased estimators with smaller deviation11. Moreover the rejections of the null hypothesis could be caused by wrong values of t-statistics and F-statistics (Asteriou \& Hall, 2011).

Note 14. In case of autocorrelation the OLS estimators are still unbiased and consistent but inefficient because it is possible to find alternative unbiased estimators with smaller variance. (As for heteroscedasticity).

The OLS estimators will be no longer BLUE and inefficient. Standard errors are underestimated. R2 would be overestimated and the t-statistics will tend to be higher (Asteriou\& Hall, 2011).

Note 15. Autocorrelation Function.

Note 16. Partial Autocorrelation Function.

Note 17 . White noise process is a process with constant mean and variance and zero auto-covariance at every lag except lag 0 assuming $y t$ normally distributed:

$$
E(y t)=\mu ; \operatorname{var}(y t)=\sigma^{2} ; y_{t}=\left\{\begin{array}{c}
\sigma^{2} \text { ift }=r \\
0 \text { otherwise }
\end{array}\right.
$$

A $95 \%$ confidence level interval could be constructed for the coefficient with $\pm 1.96 \times 1 / \sqrt{ } \mathbf{t}$ (where $t$ is the number of observations), therefore, the autocorrelation will be significant if presents value out of this range (Brooks, 2014).

Note 18. It is worth to specify that the study has retrieved available data at November 2016. This means that the exact value of REIT green certified square meters has not been found available at periods prior to 2016. Thus, the selection criteria (20\% portfolio greenness) has been based at 2016 , and assumed being constant since the starting period. The major consideration that has to be done is that even though the exact green percentage was not retrievable, the study has considered as green all those REITs that presented a particular inclination of sustainable investments, CSR and SRI.

The creation of the dummy variable known as Greenness has therefore been based on these predispositions of fund managers to Green and Sustainable investments, with a legacy dated more than just 6 years.

Note 19.

$$
d=\frac{\sum_{t-1}^{n}\left(\hat{u}_{t}-\hat{u}_{t-1}\right)^{2}}{\sum_{t-1}^{n} \hat{u}_{t}^{2}}=d \approx 2(1-\hat{\rho}) \quad \mathrm{d} \in[0 ; 4]
$$

Note 20. Savin, N. and White, K. (1977). The Durbin-Watson Test for Serial Correlation with Extreme Sample Sizes or Many Regressors. Econometrica, 45(8), 1989. 


\section{Appendix}

Table A. Country incidence in the Green subsample (\%)

\begin{tabular}{ll}
\hline Austria & $2 \%$ \\
Greece & $2 \%$ \\
Italy & $4 \%$ \\
Spain & $4 \%$ \\
Belgium & $6 \%$ \\
Finland & $6 \%$ \\
Germany & $6 \%$ \\
Switzerland & $6 \%$ \\
Netherlands & $9 \%$ \\
Sweden & $9 \%$ \\
France & $15 \%$ \\
United Kingdom & $32 \%$ \\
\hline
\end{tabular}

Table B. Average Green \% in REITs portfolio by Country

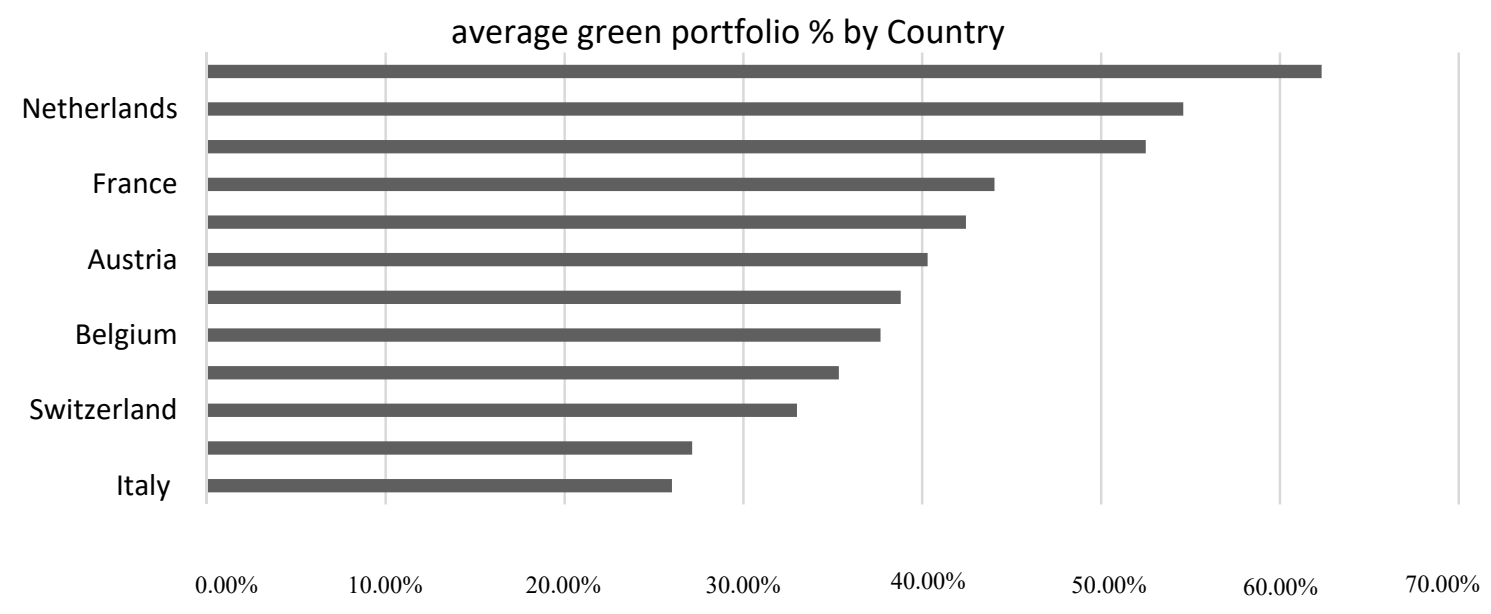

Table C. Multicollinearity test. Applied model

\begin{tabular}{|c|c|c|c|c|c|c|c|c|c|c|}
\hline & Alpha & Beta & ROE & ROA & $\operatorname{Ln}(\mathrm{TAs})$ & Debt ratio & Price/Book & Age & Sqm & Greenness \\
\hline Alpha & 1 & & & & & & & & & \\
\hline Beta & 0.729 & 1 & & & & & & & & \\
\hline ROE & 0.032 & 0.019 & 1 & & & & & & & \\
\hline ROA & 0.108 & 0.111 & 0.572 & 1 & & & & & & \\
\hline $\operatorname{Ln}(\mathrm{TAs})$ & 0.008 & -0.014 & 0.140 & 0.128 & 1 & & & & & \\
\hline Debt ratio & -0.023 & -0.077 & -0.048 & -0.083 & 0.007 & 1 & & & & \\
\hline Price/Book & 0.077 & 0.038 & -0.188 & -0.094 & 0.297 & 0.012 & 1 & & & \\
\hline Age & 0.045 & 0.051 & -0.006 & -0.116 & -0.305 & 0.209 & -0.199 & 1 & & \\
\hline $\mathrm{Sqm}$ & 0.081 & 0.082 & 0.028 & 0.011 & 0.209 & -0.012 & 0.074 & -0.023 & 1 & \\
\hline Greenness & -0.003 & -0.023 & 0.126 & 0.090 & 0.166 & 0.058 & 0.209 & -0.189 & 0.094 & 1 \\
\hline
\end{tabular}

\section{Copyrights}

Copyright for this article is retained by the author(s), with first publication rights granted to the journal.

This is an open-access article distributed under the terms and conditions of the Creative Commons Attribution license (http://creativecommons.org/licenses/by/4.0/). 